\title{
IKLIM KOMUNIKASI DAN PARTISIPASI DALAM PROGRAM PERTANIAN PERKOTAAN
}

\author{
Communication Climate and Participation in Urban Farming \\ Program \\ Nizzatul Amaliyah ${ }^{1}$, Sarwititi Sarwoprasodjo ${ }^{2}$ \\ ${ }^{1}$ Mahasiswa Departemen Sains Komunikasi dan Pengembangan Masyarakat, \\ Fakultas Ekologi Manusia, Institut Pertanian Bogor \\ ${ }^{2}$ Dosen Departemen Sains Komunikasi dan Pengembangan Masyarakat, \\ Fakultas Ekologi Manusia, Institut Pertanian Bogor
}

E-mail : nizza.amaliyah@gmail.com

\begin{abstract}
Urban farming programs are considered capable of overcoming problems in the city such as food availability. Urban farming activities can be successful if people participate. This study aims to analyze the relationship of individual characteristics with participation level in urban agriculture program, analyzing climate communication relationship of KWT Dahlia Indah and KWT Nusa Indah Lestari with participation level, and to analyze the relationship of participation level in the success of urban farming program in KWT Dahlia Indah and KWT Nusa Indah Lestari. The method used in this study is a quantitative method with a questionnaire instrument and supported by qualitative data with in-depth interviews of informants and respondents using question guides. The results of this study indicate that individual characteristics are not related to the level of participation. The existing communication climate in KWT is supportive and related to the level of participation. While the level of participation has a significant relationship with the success rate of urban farming program.
\end{abstract}

Keywords : communication climate, level of participation, the success of the program, urban farming

\begin{abstract}
ABSTRAK
Program pertanian perkotaan dianggap mampu mengatasi masalah yang ada di kota seperti masalah kerusakan lingkungan. Adanya pelibatan masyarakat dalam kegiatan tersebut diperlukan untuk mencapai tujuan dari program pertanian perkotaan. Penelitian ini bertujuan untuk menganalisis hubungan karakteristik anggota dengan tingkat partisipasi dalam program pertanian perkotaan, menganalisis hubungan iklim komunikasi KWT Dahlia Indah dan KWT Nusa Indah Lestari dengan tingkat partisipasi, serta menganalisis hubungan tingkat partisipasi dengan keberhasilan program pertanian perkotaan di KWT Dahlia Indah dan KWT Nusa Indah Lestari. Strategi yang digunakan dalam penelitian ini adalah metode sensus dengan instrumen kuesioner dan wawancara mendalam. Hasil penelitian ini menunjukkan bahwa karakteristik anggota tidak berhubungan dengan tingkat partisipasi. Iklim komunikasi yang ada dikedua KWT bersifat supportive dan memiliki hubungan yang positif dengan tingkat partisipasi, Sedangkan tingkat partisipasi memiliki hubungan yang positif dengan tingkat keberhasilan program pertanian perkotaan (urban farming).
\end{abstract}

Kata Kunci : iklim komunikasi, keberhasilan program, pertanian perkotaan, tingkat partisipasi 


\section{PENDAHULUAN}

Perkotaan merupakan pemukiman yang terdiri atas tempat tinggal dan tempat kerja masyarakat yang cenderung memiliki banyak masalah. Salah satu masalah yang dihadapi perkotaan yakni pertumbuhan penduduk perkotaan yang sangat pesat dibandingkan dengan pertumbuhan penduduk pedesaan (Fahrizal dan Oktara 2011). Di Indonesia, data BPS (2014) menunjukkan bahwa persentase penduduk perkotaan pada tahun 2010 mencapai 49,8 persen, pada tahun 2015 mencapai 53,3 persen, dan diduga pada tahun 2020 akan mencapai 56,7 persen. Peningkatan jumlah penduduk akan menimbulkan berbagai masalah, seperti masalah pangan dan lingkungan, mulai dari konversi lahan hingga degradasi kualitas lingkungan akibat sampah dan polusi (Fauzi et al. 2016). Kondisi ini memerlukan perhatian pemerintah kota untuk menyikapinya. Oleh sebab itu, dibutuhkan suatu program pemberdayaan masyarakat untuk mengatasi masalah degradasi lingkungan dan ketersediaan pangan.

Menurut Korir et al. (2015), salah satu program yang dapat ditempuh untuk mengatasi masalah kerusakan lingkungan dan pemenuhan pangan masyarakat perkotaan adalah dengan menerapkan program urban farming atau pertanian perkotaan. Kegiatan pertanian perkotaan memiliki peran yang sangat penting karena dibutuhkan dalam mendukung ketahanan pangan, kemampuan untuk mengakses pangan, dan ketergantungan makanan dari pihak manapun. Maka posisi petani dalam kegiatan pertanian perkotaan memiliki potensi strategis untuk mendukung ketahanan pangan (Cahya 2016). Selain itu, pertanian perkotaan di banyak kota memainkan peran penting dalam mempertahankan integritas lingkungan dan memberikan kontribusi signifikan terhadap pencapaian ketahanan pangan oleh peningkatan kesejahteraan masyarakat miskin perkotaan, melalui budidaya berbagai tanaman ternak dengan hasil yang cukup besar (Korir et al. 2015).

Program pertanian perkotaan sudah diterapkan di beberapa daerah di Indonesia, tak terkecuali di DKI Jakarta. Pada tahun 2016, pemerintah Daerah Khusus Ibukota (DKI) Jakarta melalui Surat Keputusan Gubernur No. 2441 tentang Pemanfaatan Tanah, meresmikan pertanian perkotaan sebagai program pemerintah. Program pertanian perkotaan di Jakarta terdiri dari tujuh sasaran ruang prioritas untuk pengembangan kegiatan pertanian perkotaan, di antaranya rumah susun (rusun), lahan kosong/tidur, lahan pekarangan dan gang perkampungan, sekolah, gedung, Ruang Publik Terbuka Ramah Anak (RPTRA), dan lahan laut. DKI Jakarta yang memiliki jumlah penduduk 10.177.924 jiwa pada tahun 2015 dengan luas $662,33 \mathrm{~km}^{2}$, diharapkan mampu menyediakan pangan secara mandiri melalui kegiatan pertanian perkotaan. Salah satu daerah di DKI Jakarta yang menerapkan program pertanian perkotaan adalah Kelurahan Petukangan Selatan, Pesanggrahan, Jakarta Selatan. Lokasi tersebut sudah menerapkan pertanian perkotaan sejak tahun 2016 dan hingga saat ini menjadi lokasi yang dianggap mandiri karena sudah mampu membeli kebutuhan sendiri dan menjadi salah satu lokasi pertanian perkotaan percontohan di Jakarta yang mencerminkan keberhasilan dari program tersebut. Keberhasilan yang sudah dicapai tidak terlepas dari keterlibatan masyarakat dalam proses perencanaan, pelaksanaan, menikmati hasil, dan evaluasi (Cohen dan Uphoff 1977). Oleh karena itu, menarik untuk diteliti bagaimana keterlibatan masyarakat dalam keberhasilan program pertanian perkotaan. 
Faktor-faktor yang mempengaruhi seseorang untuk berpartisipasi dalam pertanian perkotaan dipengaruhi oleh berbagai faktor yang berasal dari individu, seperti faktor sosial ekonomi (Gamhewage et al. 2015). Selain faktor sosial ekonomi, ternyata motif seseorang untuk melakukan sebuah kegiatan juga berpengaruh terhadap tingkat partisipasi masyarakat. Keputusan seseorang untuk berpartisipasi juga dapat dilihat dari iklim komunikasi yang ada di dalam kelompok (Beebe dan Masterson 2015), apakah suasana dalam kelompok mendukung atau menghambat anggota kelompok dalam berpartisipasi. Ida (2013) dalam penelitiannya menyebutkan bahwa iklim komunikasi memberi pedoman bagi keputusan dan perilaku individu. Hal ini juga menarik untuk diteliti bagaimana faktor-faktor yang terdapat dalam individu mempengaruhi partisipasi masyarakat dalam suatu program.

Kajian-kajian sebelumnya tentang program pertanian perkotaan hanya sebatas bagaimana pelaksanaan program tersebut dan bagaimana pengaruhnya terhadap perekonomian keluarga (Gamhewage et al. 2015). Penelitian Junainah et al. (2016) juga meneliti implementasi program pertanian perkotaan dan dampaknya dalam mengentaskan kemiskinan. Namun, pada penelitian ini menggunakan variabel iklim komunikasi untuk melihat apakah suasana dalam kelompok di KWT Dahlia Indah dan KWT Nusa Indah Lestari mendukung seseorang untuk terlibat dalam suatu program dan apakah hal itu berhubungan degan keputusan seseorang untuk berpartisipasi.

Oleh karena itu, tujuan utama dari penelitian ini yaitu menganalisis hubungan tingkat partisipasi dengan tingkat keberhasilan program pertanian perkotaan. Sedangkan tujuan spesifik dari penelitian ini yaitu (1) Menganalisis hubungan karakteristik individu dengan tingkat partisipasi dalam program pertanian perkotaan; (2) Menganalisis hubungan iklim komunikasi Kelompok Wanita Tani Dahlia Indah dan Kelompok Wanita Tani Nusa Indah Lestari dengan tingkat partisipasi; dan (3) Menganalisis hubungan tingkat partisipasi dengan tingkat keberhasilan program pertanian perkotaan di Kelompok Wanita Tani Dahlia Indah dan Kelompok Wanita Tani Nusa Indah Lestari.

\section{TINJAUAN PUSTAKA}

\section{Iklim Komunikasi}

Menurut Beebe dan Masterson (2015), iklim komunikasi dalam suatu kelompok merupakan analogi dari sebuah iklim geografis yang sehari-hari dikenal dan dirasakan yang biasa disebut dengan cuaca atau suhu. Seseorang mungkin berpartisipasi dalam kelompok yang memiliki rasa hangat dan keramah-tamahan yang sungguh-sungguh, kepercayaan, keakraban, dan kemahiran. Iklim komunikasi yang penuh persaudaraan mendorong anggota kelompok berkomuniksai secara terbuka, rileks, ramah tamah dengan anggota lain. Iklim komunikasi defensive dan supportive merupakan iklim komunikasi dalam kelompok yang memiliki karakteristik berbeda satu sama lain. Iklim yang defensive terdiri dari evaluasi (evaluation), kontrol (control), strategi (strategy), netralitas (netrality), superioritas (superiority), dan kepastian (certainty), sedangkan iklim yang supportive terdiri dari deskripsi (description), orientasi masalah (problem orientation), spontanitas (spontanity), empati (emphaty), persamaan (equality), dan sementara (provisionalism). 


\section{Partisipasi}

Cohen dan Uphoff (1977) mendefinisikan partisipasi sebagai keterlibatan masyarakat mulai dari perencanaan, pelaksanaan, menikmati hasil dan evaluasi. Tahap perencanaan bermaksud untuk melihat sejauh mana kesadaran masyarakat dalam memberikan penilaian dan menentukan pemilihan sesuai dengan kebutuhan mereka sendiri yang diwujudkan dengan keikutsertaan masyarakat dalam rapatrapat. Tahap pelaksanaan, merupakan tahap terpenting dalam pembangunan, sebab inti dari pembangunan adalah pelaksanaannya. Wujud nyata partisipasi pada tahap ini digolongkan menjadi tiga, yaitu partisipasi dalam bentuk sumbangan pemikiran, bentuk sumbangan materi, dan bentuk tindakan sebagai anggota proyek. Tahap menikmati hasil, dapat dijadikan indikator keberhasilan partisipasi masyarakat pada tahap perencanaan dan pelaksanaan proyek. Pada tahap ini, masyarakat bisa merasakan manfaat dari proyek, apakah berhasil mengenai sasaran atau tidak. Tahap evaluasi, dianggap penting sebab partisipasi masyarakat pada tahap ini merupakan umpan balik yang dapat memberi masukan demi perbaikan pelaksanaan proyek selanjutnya. Pada tahapan ini masyarakat setingkat lebih memahami kegunaan dan kerugian dari suatu program yang diberikan sehingga mereka dapat menyusun dan mengeksekusi solusi atas penilaian mereka.

\section{Pertanian Perkotaan (Urban Farming)}

Menurut Sihgiyanti (2016) urban farming merupakan aktivitas pertanian di sekitar perkotaan yang melibatkan keterampilan, keahlian, dan inovasi dalam budidaya pengelolaan makanan bagi masyarakat miskin melalui pemanfaatan pekarangan, lahan-lahan kosong guna memenuhi kebutuhan gizi keluarga, meningkatkan perekonomian keluarga, serta memotivasi keluarga miskin untuk membentuk suatu kelompok pertanian guna membangun kemandirian rumah tangga. Kegiatan pertanian perkotaan pada penelitian ini difokuskan pada budidaya hidroponik. Tanaman hidroponik adalah tanaman yang ditanam dengan pemanfaatan air dan tanpa penggunaan tanah sebagai media tanam (Tallei et al. 2017).

Pada penelitian ini kegiatan pertanian perkotaan difokuskan kepada kelompok tani, khususnya wanita atau yang disebut dengan kelompok wanita tani. Pemilihan kelompok wanita tani dikarenakan penulis ingin mengetahui bagaimana sekelompok wanita dapat bekerja sama untuk mewujudkan pemenuhan pangan secara mandiri. Menurut Lanarc (2013), terdapat beberapa tujuan dari kegiatan pertanian perkotaan, di antaranya: (1) Meningkatnya ketersediaan pangan; (2) Meningkatkan inovasi; (3) Pengurangan limbah; (4) Meningkatnya kebersihan lingkungan; dan (5) Meningkatnya pembelajaran.

\section{Karakteristik Anggota}

Menurut Gamhewage et al. (2015) terdapat faktor sosio-ekonomi yang mempengaruhi seseorang berpartisipasi. Faktor sosio-ekonomi tersebut di antaranya, usia, tingkat pendidikan, jumlah anggota keluarga, dan pendapatan per bulan. Selain faktor sosio-ekonomi yang terdapat di dalam diri masyarakat, terdapat pula motif yang melatarbelakangi masyarakat untuk berpartisipasi. Kata "motif" diartikan sebagai daya upaya yang mendorong seseorang untuk melakukan sesuatu. Menurut Sardiman (2004), motif dapat dikatakan sebagai daya penggerak dari dalam dan di dalam subjek untuk melakukan aktivitasaktivitas tertentu demi mencapai suatu tujuan. 


\section{Kerangka Pemikiran}

Program pertanian perkotaan merupakan salah satu bentuk komunikasi pembangunan yang diinisiatif oleh pemerintah DKI Jakarta, dalam hal ini Dinas Ketahanan Pangan, Kelautan, dan Pertanian (KPKP) kepada masyarakat kelompok wanita tani Dahlia Indah dan Nusa Indah Lestari sebagai pelaksana program melalui komunikasi kelompok yang terdapat di kelompok wanita tani.

Program pertanian perkotaan menjadi salah satu program yang dapat ditempuh untuk mengatasi masalah kerusakan lingkungan di perkotaan. Keikutsertaan seseorang dalam suatu program dipengaruhi oleh faktor sosioekonomi dan motif. Faktor sosio-ekonomi dan motif dapat dikatakan sebagai karakteristik anggota, karena faktor-faktor tersebut muncul dari diri seseorang. Selain itu, untuk mengetahui bagaimana seseorang dapat berpartisipasi dapat dilihat melalui iklim komunikasi yang terjadi di kelompoknya. Karakteristik anggota dan iklim komunikasi menjadi faktor yang mempengaruhi tingkat partisipasi seseorang dalam program pertanian perkotaan.

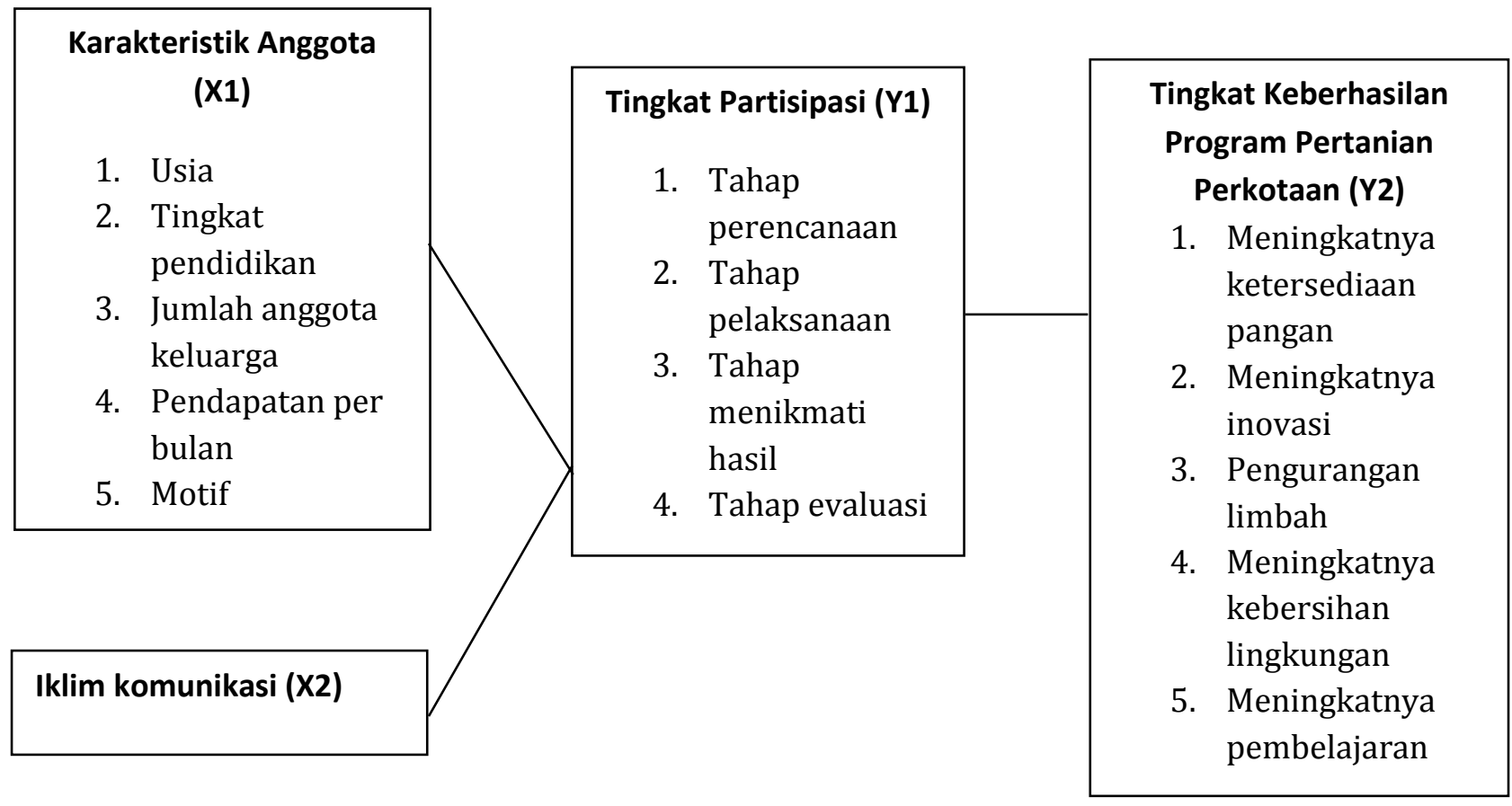

Keterangan: : Berhubungan

Gambar 1 Kerangka pemikiran hubungan iklim komunikasi dan partisipasi dalam program pertanian perkotaan

\section{METODE PENELITIAN}

Strategi yang digunakan dalam penelitian ini adalah metode sensus terhadap seluruh anggota populasi dengan instrumen kuesioner dan wawancara mendalam. Populasi penelitian ini adalah Kelompok Wanita Tani (KWT) Dahlia Indah (RW 01, Kelurahan Petukangan Selatan, Jakarta Selatan, DKI Jakarta) yang berjumlah 20 orang dan Kelompok Wanita Tani (KWT) Nusa Indah Lestari (RW 06, Kelurahan Petukangan Selatan, Jakarta Selatan, DKI Jakarta) yang berjumlah 14 orang. Jumlah populasi dalam penelitian ini adalah 34 orang. Lokasi tersebut 
dipilih dengan beberapa pertimbangan, yaitu (1) program pertanian perkotaan di Petukangan Selatan menjadi daerah percontohan pertanian perkotaan di Kotamadya Jakarta Selatan, (2) program pertanian perkotaan ini cukup unik, karena memanfaatkan lahan sempit untuk melakukan kegiatan pertanian, (3) KWT Dahlia Indah dan KWT Nusa Indah Lestari memiliki beberapa kemiripan terkait materi yang disampaikan oleh penyuluh dalam pelaksanaan program pertanian perkotaan. Kegiatan penelitian ini dilaksanakan dari bulan Maret 2018 sampai Juli 2018.

Penelitian ini mempunyai dua jenis data yang diolah dan dianalisis, yaitu data kuantitatif dan data kualitatif. Data kuantitatif yang didapatkan dari hasil kuesioner responden diolah dengan tahapan coding, entry, editing, dan analisis data. Data kuantitatif tersebut kemudian disajikan ke dalam bentuk tabel frekuensi, tabulasi silang. Analisis data yang digunakan adalah uji korelasi Rank Spearman dengan aplikasi SPSS 16.0.

\section{HASIL DAN PEMBAHASAN}

\section{Profil KWT Nusa Indah Lestari}

Berlokasi di RW 06, Kelurahan Petukangan Selatan, Kecamatan Pesanggrahan, Jakarta Selatan, KWT ini berdiri sejak tahun 2017 atas anjuran dari Sudin Ketahanan Pangan, Kelautan, dan Pertanian (KPKP) Kecamatan Pesanggrahan. Awal dari berdirinya KWT ini bermula dari kegiatan gang hijau yang dilaksanakan di RW 06, hingga pada tahun 2016 mendapatkan bantuan dari Dinas KPKP berupa pot, bibit, dan media tanam. Berkembangnya kegiatan gang hijau di lokasi tersebut, membuat penyuluh dari Sudin KPKP mengusulkan lokasi tersebut untuk membuat KWT. Hingga pada Februari 2017, dibentuklah kelompok wanita tani bernama Nusa Indah Lestari. Salah satu tokoh yang sangat berperan dalam pembentukan KWT ini ialah penyuluh di Sudin KPKP Kecamatan Pesanggrahan. Kelompok Wanita Tani yang berjumlah 15 orang ini terdiri dari ketua yang dibantu oleh sekretaris, bendahara, dan anggota dalam menjalankan KWT ini.

Selain memanfaatkan gang untuk dihijaukan, kelompok ini juga memanfaatkan lahan kosong untuk dijadikan kegiatan pertanian. Lahan kosong tersebut merupakan milik PT Jasa Marga yang berada di sekitar wilayah Jakarta Outer Ring Road (JORR) dengan luas $100 \mathrm{~m}$ yang dapat digunakan oleh KWT Nusa Indah Lestari. Saat ini, KWT Nusa Indah Lestari difokuskan pada budidaya hidroponik yang dianggap tepat untuk melakukan kegiatan pertanian di perkotaan dengan lahan yang sempit. Selain itu, KWT ini merupakan KWT pelopor yang menerapkan budidaya hidroponik di Kelurahan Petukangan Selatan. Hingga pada tahun 2017, ketua KWT Nusa Indah Lestari terpilih sebagai champion Jakarta Selatan dalam kegiatan pertanian perkotaan. Arti champion sendiri memiliki arti bahwa penggiat (dalam hal ini ketua) pertanian perkotaan aktif dalam merawat lahannya dan sering memberikan laporan ketika ada kegiatan ataupun kunjungan. Hal ini juga memperlihatkan bahwa KWT Nusa Indah Lestari sudah mampu membelikan kebutuhan mereka seperti membeli benih, sekam, dan nutrisi.

\section{Profil KWT Dahlia Indah}

Kelompok wanita tani lainnya yang berada di Kelurahan Petukangan Selatan, Kelurahan Pesanggrahan, Jakarta Selatan ialah Kelompok Wanita Tani (KWT) Dahlia Indah. KWT Dahlia Indah berada di RW 01 dan sudah berdiri 
sejak November 2017 ini memiliki penyuluh yang sama dengan KWT Nusa Indah Lestari. Jumlah anggota di KWT Dahlia Indah berjumlah 20 orang yang terdiri dari ketua, wakil ketua, sekretaris, bendahara, dan beberapa seksi. Lahan yang digunakan KWT Dahlia untuk melakukan kegiatan pertanian perkotaan merupakan lahan milik PT Jasa Marga yang terdapat di daerah Jakarta Outer Ring Road (JORR) dengan luas sekitar 10 x 200 meter.

Jenis sayuran yang ditanam di KWT Dahlia Indah ialah kangkung, selada, bayam hijau, bayam merah, daun selada, dan pakcoy. Manfaat dari hasil panen umumnya dijual dan ketika terdapat sisa panen baru dikonsumsi oleh anggota KWT. Penjualan hasil panen nantinya akan dibelikan nutrisi untuk tanaman hidroponik.

\section{Karakteristik Anggota}

Karakteristik anggota terdiri atas usia, tingkat pendidikan, jumlah anggota keluarga, pendapatan per bulan, dan motif seseorang untuk melakukan sebuah kegiatan atau aktivitas. Jumlah dan persentase mayoritas responden berdasarkan karakteristik anggota tersaji di Tabel 1.

Tabel 1 Jumlah dan persentase responden berdasarkan karakteristik anggota di KWT Nusa Indah Lestari dan KWT Dahlia Indah tahun 2018

\begin{tabular}{lcc}
\hline Karakteristik anggota & Kategori & Persentase (\%) \\
\hline Usia & $39-48$ tahun & 55.9 \\
Tingkat pendidikan & SMA/Tamat SMA & 67.6 \\
Jumlah anggota keluarga & $3-5$ orang & 58.8 \\
Tingkat pendapatan per bulan & Rp 1.450.000 - Rp 3.000.000 & 47.1 \\
Tingkat motif & Rendah & 73.5 \\
\hline
\end{tabular}

Berdasarkan hasil penelitian, diketahui bahwa mayoritas responden cukup produktif untuk berpartisipasi dalam program pertanian perkotaan. Hal ini dilihat pada usia responden yang termasuk ke dalam usia madya (Putri et al. 2016). Pendidikan formal yang cukup memadai untuk ikut terlibat dalam suatu program, dan tingkat pendapatan yang menunjukkan bahwa mayoritas responden memiliki kehidupan yang cukup layak dan dapat menghidupi kebutuhannya sehari-hari.

\section{Iklim Komunikasi}

Pada penelitian ini, terdapat enam pertanyaan untuk menentukan apakah iklim komunikasi pada KWT termasuk ke dalam iklim defensive atau supportive. Tabel 2 menunjukkan jumlah dan persentase responden berdasarkan iklim komunikasi di KWT Nusa Indah Lestari dan KWT Dahlia Indah.

Terdapat beberapa indikator untuk mengetahui apakah suatu kelompok memiliki suasana supportive atau defensive. Indikator yang terkait dengan suasana kelompok yang bersifat defensive seperti evaluasi, kontrol, strategi, netralitas, superioritas, kepastian. Adapun indikator yang menyatakan apakah kelompok itu bersifat supportive adalah deskripsi, orientasi masalah, spontanitas, empati, persamaan, dan sementara. 
Tabel 2 Persentase responden berdasarkan iklim komunikasi dan aspek iklim komunikasi di KWT Nusa Indah Lestari dan KWT Dahlia Indah tahun 2018

\begin{tabular}{|c|c|c|c|c|c|c|c|}
\hline \multirow[b]{2}{*}{ No. } & \multirow[b]{2}{*}{ Pernyataan } & \multirow{2}{*}{$\begin{array}{l}\text { Aspek iklim } \\
\text { komunikasi } \\
\text { defensive }\end{array}$} & \multicolumn{4}{|c|}{ Jawaban } & \multirow{2}{*}{$\begin{array}{l}\text { Aspek iklim } \\
\text { komunikasi } \\
\text { supportive }\end{array}$} \\
\hline & & & $\begin{array}{c}1 \\
(\%)\end{array}$ & $\begin{array}{c}2 \\
(\%)\end{array}$ & $\begin{array}{c}3 \\
(\%)\end{array}$ & $\begin{array}{c}4 \\
(\%)\end{array}$ & \\
\hline 1. & $\begin{array}{l}\text { Menjelaskan } \\
\text { cara } \\
\text { menyemai }\end{array}$ & Evaluasi & 5.9 & 14.7 & 47.1 & 32.4 & Deskripsi \\
\hline 2. & $\begin{array}{l}\text { Pengendalian } \\
\text { terhadap } \\
\text { tanaman } \\
\text { yang mati }\end{array}$ & Kontrol & 0.0 & 11.8 & 58.8 & 29.4 & $\begin{array}{l}\text { Orientasi } \\
\text { masalah }\end{array}$ \\
\hline 3. & $\begin{array}{l}\text { Cara } \\
\text { beriteraksi } \\
\text { dengan } \\
\text { anggota }\end{array}$ & Strategi & 5.9 & 41.2 & 17.6 & 35.3 & Spontanitas \\
\hline 4. & $\begin{array}{l}\text { Membantu } \\
\text { memasukkan } \\
\text { bibit ke } \\
\text { paralon }\end{array}$ & Netralitas & 0.0 & 5.9 & 58.8 & 35.3 & Empati \\
\hline 5. & $\begin{array}{l}\text { Anggota } \\
\text { wajib } \\
\text { melakukan } \\
\text { kegiatan } \\
\text { pertanian } \\
\text { perkotaan }\end{array}$ & Superioritas & 0.0 & 0.0 & 38.2 & 61.8 & Persamaan \\
\hline 6. & $\begin{array}{l}\text { Hasil } \\
\text { hidroponik } \\
\text { bisa } \\
\text { dijadikan } \\
\text { smothies }\end{array}$ & Kepastian & 0.0 & 0.0 & 20.6 & 79.4 & Sementara \\
\hline
\end{tabular}

Suasana kelompok yang terdapat di kedua KWT mencerminkan bahwa anggota kelompok sering diberitahu bagaimana cara menyemai yang benar oleh anggota lain. Ketika ada masalah tentang tanaman yang mati, anggota seringkali mendiskusikan hal tersebut. Dalam berkomunikasi, mayoritas anggota masih bersikap harus berbasa-basi terlebih dahulu kepada anggota lain. Hal ini dikarenakan perbedaan usia yang ada diantara anggota KWT yang cukup jauh. Meski begitu, anggota masih menerapkan prinsip tolong menolong dalam bertanam secara hidroponik. Anggota dikedua KWT memiliki latar belakang yang berbeda, namun itu semua tidak mempengaruhi kinerja dari masing-masing anggota karena semua anggota dianggap setara dan harus berkomitmen terhadap seluruh kegiatan yang ada di KWT. Dalam bertukar pikiran, seluruh anggota mampu mengubah pengetahuan yang lama dengan yang baru, contohnya ialah bahwa hasil panen hidroponik tidak hanya dibuat sayuran tetapi bisa dibuat smoothies pakcoy dan keripik. Berdasarkan hal diatas dapat disimpulkan bahwa 
suasana yang tercipta di dalam KWT Dahlia Indah dan KWT Nusa Indah Lestari bersifat supportive.

\section{Tingkat Partisipasi}

Pogram pertanian perkotaan (urban farming) di KWT Nusa Indah Lestari dan KWT Dahlia melibatkan anggota untuk ikut serta secara aktif dalam pelaksanaan program pertanian perkotaan, seperti adanya rapat perencanaan dengan penyuluh, kegiatan menyemai, kegiatan memanen, menjual hasil panen kepada orang lain, hingga rapat evaluasi. Berikut jumlah dan persentase responden tingkat partisipasi di KWT Nusa Indah Lestari dan KWT Dahlia Indah.

Tabel 3 Persentase responden berdasarkan tingkat partisipasi di KWT Nusa Indah Lestari dan KWT Dahlia Indah tahun 2018

\begin{tabular}{lc}
\hline Tingkat partisipasi & Persentase $(\%)$ \\
\hline Tingkat partisipasi & 53.2 \\
Tahap perencanaan & 37.5 \\
Tahap pelaksanaan & 72.9 \\
Tahap menikmati hasil & 71.4 \\
Tahap evaluasi & 31.1 \\
\hline
\end{tabular}

Hasil pengamatan di lapangan menunjukkan bahwa tidak semua anggota selalu datang setiap hari ke KWT, hal ini dikarenakan mayoritas responden harus mengerjakan pekerjaan rumah terlebih dahulu, seperti membersihkan rumah, mengantar anak sekolah, dan memasak, jika kegiatan tersebut sudah dilaksanakan baru responden pergi ke KWT. Partisipasi dikedua KWT menunjukkan masih dalam kategori sedang.

Pada tahap perencanaan, setiap anggota KWT selalu hadir ketika ada rapat dengan penyuluh. Namun, kontribusi anggota dalam bertanya, memberikan pendapat, serta mengambil keputusan pada rapat tersebut dinilai masih kurang. Biasanya yang selalu aktif dalam bertanya dan memberikan pendapat ialah ketua KWT. Pada tahap pelaksanaan, seluruh anggota KWT memang cenderung melakukan kegiatan pertanian perkotaan. Namun, dalam kegiatan memberikan nutrisi seringkali hanya beberapa orang saja yang melakukan. Hal ini disebabkan karena orang tersebut dianggap paling tahu dalam menakar ukuran nutrisi untuk tanaman hidroponik.

Pada tahap menikmati hasil, seluruh responden merasakan hasil dari adanya tanaman hidroponik berupa lingkungan yang sehat dan indah. Kemudian, responden merasakan keuntungan ekonomi dari adanya penjualan hasil panen hidroponik. Sedangkan pada tahap evaluasi, responden selalu hadir dalam rapat evaluasi yang diadakan dengan penyuluh. Namun, dalam hal memberikan penilaian, saran, dan kritik dinilai masih kurang. Hal ini disebabkan karena sebagian kecil yang memberikan penilaian dan saran adalah orang-orang yang dianggap mengerti betul tentang perkembangan tanaman hidroponik. Tetapi untuk memberikan kritik, anggota KWT tidak pernah memberikan kritik karena mereka menganggap bahwa dirinya pun masih belajar tentang hidroponik dan belum mampu mengkritik tentang tanaman yang ada di KWT. 


\section{Tingkat Keberhasilan Program Pertanian Perkotaan (Urban Farming)}

Tingkat keberhasilan program pertanian perkotaan adalah tercapainya tujuan program pertanian perkotaan yang telah dilaksanakan oleh responden melalui beberapa indikator. Indikator tersebut di antaranya, (1) meningkatnya ketersediaan pangan, (2) meningkatnya inovasi, (3) pengurangan limbah, (4) meningkatnya kebersihan lingkungan, dan (5) meningkatnya pembelajaran. Tabel 4 menjelaskan jumlah dan persentase tingkat keberhasilan program pertanian perkotaan (urban farming) di KWT Nusa Indah Lestari dan KWT Dahlia.

Tabel 4 Persentase responden berdasarkan tingkat keberhasilan program di KWT Nusa Indah Lestari dan KWT Dahlia Indah tahun 2018

\begin{tabular}{lc}
\hline Tingkat keberhasilan program pertanian perkotaan & Persentase $(\%)$ \\
\hline Tingkat keberhasilan program pertanian perkotaan & 53.5 \\
Tingkat ketersediaan pangan & 66.9 \\
Tingkat inovasi & 26.1 \\
Tingkat pengurangan limbah & 37.6 \\
Tingkat kebersihan lingkungan & 66.7 \\
Tingkat pembelajaran & 70.0 \\
\hline
\end{tabular}

Hasil pengamatan di lapangan menunjukkan bahwa, responden belum sepenuhnya merasakan manfaat dari adanya program pertanian perkotaan ini. Karena sebagian besar dari responden hanya menanam secara hidroponik di KWT, hanya sebagian kecil yang menanam hidroponik di rumah. Hal ini disebabkan karena terbatasnya lahan di rumah responden. Sehingga responden hanya melakukan kegiatan pertanian perkotaan di KWT. Dalam hal ketersediaan pangan, responden juga mengaku hasil panen dari hidroponik belum mampu memenuhi kebutuhan sayuran karena sebagian besar hasil panen hidroponik dijual yang nantinya hasil dari penjualan akan dibelikan nutrisi, sekam, dan tanah untuk kebutuhan hidroponik. Namun, hal responden mengaku bahwa kini lingkungannya lebih sehat semenjak ada program pertanian perkotaan dibandingkan dengan sebelumnya. Selain itu, anggota KWT diberi pelatihan oleh penyuluh untuk mengubah hasil panen menjadi bentuk olahan, seperti smoothies pakcoy dan keripik. Dalam hal pengurangan limbah, anggota KWT sudah mampu melakukan aksi pengurangan limbah dengan memilah sampah dan memanfaatkan barang yang tidak terpakai. Namun, dalam hal mengolah sampah menjadi kompos dirasa belum dilakukan responden. Sedangkan dalam hal pembelajaran, anggota KWT dapat menjelaskan tahapan dalam menanam secara hidroponik, meskipun masih terdapat beberapa responden yang menjelaskannya tidak secara lengkap.

\section{Hubungan Karakteristik Anggota, Iklim Komunikasi dan Partisipasi Dalam Program Pertanian Perkotaan}

Hubungan antara karakteristik anggota dan iklim komunikasi dengan tingkat partisipasi, dan hubungan tingkat partisipasi dengan program pertanian perkotaan (urban farming) dianalisis menggunakan uji statistik rank spearman. Pengambilan keputusan diambil berdasarkan nilai Sig. Jika Sig. (2-tailed) atau p-value lebih kecil dari taraf nyata $(\alpha)=0.05$, maka $\mathrm{H} 0$ ditolak yang artinya terdapat hubungan yang signifikan antara variabel-variabel yang diuji. Tanda bintang (*) pada koefisien korelasi menunjukkan adanya hubungan antara variabel yang diuji. 
Tabel 5 Nilai koefisien korelasi antara karakteristik anggota, iklim komunikasi, tingkat partisipasi dan tingkat keberhasilan program di KWT Nusa Indah Lestari dan KWT Dahlia Indah tahun 2018

\begin{tabular}{lll}
\hline & Tingkat partisipasi & Tingkat keberhasilan program \\
\hline Usia & 0.221 & - \\
Tingkat pendidikan & -0.130 & - \\
Jumlah anggota keluarga & 0.171 & - \\
Tingkat pendapatan per bulan & 0.163 & - \\
Motif & 0.122 & - \\
Iklim komunikasi & $0.497 * *$ & - \\
Tingkat partisipasi & - & $0.665^{* *}$ \\
\hline$* *$ nyata pada -value $=0.01$ & &
\end{tabular}

\section{Hubungan Karakteristik Anggota dengan Tingkat Partisipasi}

Berdasarkan Tabel 5, dapat disimpulkan bahwa usia, tingkat pendidikan, jumlah anggota keluarga, tingkat pendapatan per bulan, dan tingkat motif tidak memiliki hubungan yang signifikan dengan tingkat partisipasi anggota KWT dalam program pertanian perkotaan. Hal ini disebabkan karena seluruh anggota memiliki kesempatan yang sama untuk terlibat didalam program tersebut. Selain itu, banyak responden yang mengeluhkan bahwa jarak dari rumah ke tempat KWT menjadi salah satu kendala mereka untuk melakukan kegiatan di KWT. Sejalan dengan penelitian Hapsari et al. (2012), yang menyatakan bahwa usia, tingkat pendidikan, tingkat pendapatan tidak memiliki hubungan dengan keterlibatan seseorang dalam kegiatan Kebun Bibit Rakyat (KBR). Hasil penelitian Ferdiani (2016) menyatakan bahwa jumlah anggota keluarga yang dimiliki responden tidak memiliki hubungan dengan tingkat partisipasi dalam kegiatan pemanfaatan lahan dan pengolahan pangan (PLP3).

\section{Hubungan Iklim Komunikasi dengan Tingkat Partisipasi}

Tabel 5 menunjukkan bahwa iklim komunikasi memiliki hubungan yang positif dengan tingkat partisipasi anggota KWT dalam program pertanian perkotaan. Data di lapang menunjukkan bahwa keakraban antar sesama anggota KWT dapat dikatakan cukup yang terlihat dari kerjasama yang terjalin, keterbukaan satu sama lain, dan saling membantu. Hal itu yang membuat keterlibatan responden dalam kegiatan pertanian perkotaan menjadi tinggi. Sejalan dengan penelitian Irawan dan Venus (2016) bahwa pengaruh iklim komunikasi organisasi terhadap kinerja pegawai berupa kepercayaan, kejujuran, keterbukaan adalah sebesar 82,1 persen, sedangkan sisanya sebesar 17,9 persen dipengaruhi oleh variabel lain. Oleh sebab itu, pengaruh iklim komunikasi organisasi baik secara langsung maupun tidak langsung berpengaruh terhadap kinerja pegawai di lingkungan Kantor Keluarga Berencana Kota Administrasi Jakarta Pusat.

\section{Hubungan Tingkat Partisipasi dengan Tingkat Keberhasilan Program Pertanian Perkotaan (Urban Farming)}

Tabel 5 menunjukkan bahwa tingkat partisipasi memiliki hubungan yang positif dengan tingkat keberhasilan program pertanian perkotaan. Hal ini ditunjukkan dengan aktifnya keikutsertaan anggota KWT pada program pertanian perkotaan (urban farming). Dalam hal ketersediaan pangan memang responden belum merasakan adanya ketersediaan sayuran dari hasil hidroponik. Hal ini disebabkan karena hasil panen hidroponik seluruhnya dijual kepada orang lain, 
anggota KWT hanya bisa merasakan hasil panen apabila terdapat sisa dari hasil panen yang tidak terjual. Meski begitu, anggota KWT tetap merasa senang karena usahaya dalam merawat tanaman hidroponik dapat dikatakan berhasil karena tanaman dapat tumbuh subur. Sedangkan dalam hal inovasi, anggota KWT merasa bahwa mendapatkan pengetahuan baru tentang cara mengolah sayuran. Biasanya, anggota KWT hanya mengolah hasil panen menjadi sayuran saja, tidak dalam bentuk lain. Menurut Junainah et al. (2016), program urban farming dapat membuat kelompok tani berubah dari kondisi tidak berdaya menjadi lebih berdaya.

Keberhasilan program pertanian perkotaan terlihat pada aspek lingkungan. Hal ini tercermin pada pelaksanaan pertanian perkotaan di KWT Nusa Indah Lestari dan KWT Dahlia Indah dalam memelihara lingkungan yang sudah terdapat bak sampah yang sudah dipisahkan jenisnya. Sehingga jika ada barang yang tidak terpakai seperti botol aqua, cup ice cream dapat dimanfaatkan sebagai media tanam. Hal ini sejalan dengan penelitian Hutagaol (2015) yang menyatakan bahwa tingkat partisipasi pada tahap pelaksanaan berhubungan secara signifikan dengan peningkatan kebersihan lingkungan pada program bank sampah.

Selain dalam hal pengolahan limbah, keberhasilan pertanian perkotaan juga dapat tercermin apabila seseorang dapat menerapkan kembali apa yang sudah diterapkan di KWT seperti menanam secara hidroponik dirumah dan merawat kebersihan di sekitar rumahnya. Data di lapang menunjukkan bahwa hanya beberapa responden yang baru menerapkan sistem hidroponik dirumahnya. Kebanyakan dari mereka baru menanam sayuran dan jumlahnya tidak banyak. Hal ini disebabkan karena terbatasnya lahan yang dimiliki oleh responden. Program pertanian perkotaan ternyata juga memberikan pembelajaran bagi anggota KWT Nusa Indah Lestari dan Dahlia Indah. Hal ini dibuktikan dengan bertambahnya pengetahuan responden tentang cara merawat tanaman dengan sistem hidroponik yang berbeda dengan pot.

\section{KESIMPULAN DAN SARAN}

Berdasarkan hasil penelitian yang telah dilakukan, maka dapat ditarik kesimpulan bahwa program pertanian perkotaan belum berhasil. Hal ini disebabkan karena hanya aspek lingkungan yang sudah tercermin keberhasilannya dan berdasarkan hasil penelitian tingkat partisipasi memiliki hubungan yang positif dengan tingkat keberhasilan program. Artinya anggota KWT terlibat secara aktif dalam program tersebut. Faktor lainnya yang mempengaruhi keberhasilan program tersebut ialah iklim komunikasi, hal ini terlihat dari adanya hubungan yang positif antara iklim komunikasi dengan tingkat partisipasi. Sedangkan karakteristik anggota tidak memiliki hubungan dengan tingkat partisipasi.

Berdasarkan hasil penelitian yang telah dilakukan, saran yang dapat diberikan dan dapat dijadikan masukan sebagai bahan pertimbangan bagi pihakpihak terkait yaitu, karakteristik anggota seperti usia, tingkat pendidikan, jumlah anggota keluarga, tingkat pendapatan per bulan, dan motif tidak menjadi fokus utama anggota KWT untuk berpartisipasi pada program pertanian perkotaan (urban farming). Iklim komunikasi yang bersifat supportive di kedua KWT sebaiknya diikuti dengan pelaksanaan kegiatan pertanian perkotaan. Dalam hal ini, anggota dapat terlibat aktif disetiap kegiatan pertanian perkotaan. Sehingga akan meningkatkan keakraban dan kerjasama diantara anggota KWT. 
Keberhasilan program pertanian perkotaan di kedua KWT masih perlu ditingkatkan lagi, agar anggota KWT dapat benar-benar merasakan adanya program tersebut terutama dalam hal ketersediaan pangan sebagai tujuan utama dari program ini. Cara yang bisa dilakukan yakni dengan membagikan hasil panen terlebih dahulu anggota KWT, kemudian sisa dari hasil panen dapat dijual. Dalam hal pengembangan produk, dapat dilakukan integrasi antara KWT dengan pelaku usaha, agar hasil produk yang telah dibuat oleh anggota KWT dapat tersebar luas. Selain itu, peran aktor penggerak dapat ditingkatkan agar potensi anggota KWT lebih meningkat dalam mengembangkan program pertanian perkotaan. Hal yang mungkin dapat dilakukan yakni dengan mengadakan pelatihan rutin tentang inovasi yang dapat dibuat dari hasil panen hidroponik. Sehingga hal ini dapat meningkatkan partisipasi anggota KWT dalam program pertanian perkotaan.

\section{DAFTAR PUSTAKA}

Beebe SA, Masterson JT. 2015. Communicating in small group: Principles and practices 11 th. Ed. Boston (US): Pearson.

[BPS] Badan Pusat Statistik. 2014. Persentase penduduk daerah perkotaan menurut provinsi. Terdapat pada: https://www.bps.go.id/statictable/2014/02/18/1276/ persentase-penduduk-daerah-perkotaan-menurut-provinsi-2010-2035.html

Cahya DL. 2016. Analysis of urban agriculture sustainability in metropolitan jakarta (case study: urban agriculture in Duri Kosambi). Procedia - Social and Behavioral Sciences [Internet]. [diunduh pada tanggal 01 November 2017]; Vol. 227: 95-100. Dapat diunduh di: https://doi.org/10.1016/j.sbspro.2016.06.048

Cohen J, Uphoff N. 1977. Participation's place in rural development: Seeking clarity through specificity. World Development [Internet]. [diunduh pada 5 Februari 2018]; Vol. 8: 213-235. Dapat diunduh di: https://doi.org/10.1016/0305750X(80)90011-X

Fahrizal S, Oktara A (2011). Peran dinas perhubungan Kota Bandar Lampug dalam perencanaan pembangunan transportasi perkotaan [skripsi]. Lampung (ID): Universitas Lampung.

Ferdiani N. 2016. Partisipasi dan perubahan perilaku anggota kelompok wanita tani di Desa Cikarawang, Kecamatan Dramaga, Kabupaten Bogor [skripsi]. Bogor (ID): Institut Pertanian Bogor.

Gamhewage MI, Sivashankar P, Mahaliyanaarachchi RP, Wijeratne AW, Hettiarachchi IC. 2015. Women participation in urban agriculture and its influence on family economy - Sri Lanka experience. The Journal of Agriculture Sciences [Internet]. [diunduh pada tanggal 10 Oktober 2017]; Vol. 10(3): 192- $206 . \quad$ Dapat diunduh di: http://doi.org/10.4038/jas.v10i3.8072

Hapsari DT, Suprijanto, Sangen M, Susilawati. 2012. Faktor-faktor yang mempengaruhi partisipasi masyarakay pada kebun bibit rakyat. Enviroscienteae [Internet]. [diunduh pada tanggal 09 Juni 2018]; Vol. 8: 55-61. Dapat diunduh di: http://ppjp.unlam.ac.id/journal/index.php/es/index

Hutagaol RA. 2015. Hubungan tingkat partisipasi dengan keberlanjutan program bank sampah PT ISM Tbk [skripsi]. Bogor (ID): Institut Pertanian Bogor.

Ida SW. 2013. Komunikasi interpersonal dan iklim komunikasi dalam organisasi. Jurnal Dakwah Tabligh [Internet]. [diunduh pada tanggal 20 Februari 2018]; Vol. 14(1): 115-126. Dapat diunduh di: http://journal.uinalauddin.ac.id/index.php/tabligh/article/view/318 
Irawan D, Venus A. Pengaruh iklim komunikasi organisasi terhadap kinerja pegawai kantor keluarga berencana Jakarta Barat. Jurnal Kajian Komunikasi [Internet]. [diunduh pada tanggal 02 Maret 2018]; Vol. 4(2): 122-132. Dapat diunduh di: http://jurnal.unpad.ac.id/jkk/article/view/7367/5321

Junainah W, Kanto S, Soenyono. 2016. Program urban farming sebagai model penanggulangan kemiskinan masyarakat perkotaan (studi kasus di kelompok tani Kelurahan Keputih, Kecamatan Sukolilo, Kota Surabaya). Wacana [Internet]. [diunduh pada tanggal 17 November 2017]; Vol. 19(3): 148-156. Dapat diunduh di: https://media.neliti.com/media/publications/164607-ID-program-urban-farminsebagai-model-pena.pdf

Korir SC, Rotich JK, Mining P. 2015. Urban agriculture and food security in developing countries: a case study of Eldoret Municipality, Kenya. European Journal of Basic and Applied Sciences [Internet]. [diunduh pada tanggal 28 September 2017]; Vol. 2(2): 27-35. Dapat diunduh di: http://www.idpublications.org/wpcontent/uploads/ 2015/06/URBAN-AGRICULTURE-AND-FOOD-SECURITY-INDEVELOPING-COUNTRIES-A-CASE-STUDY-OF-ELDORETMUNICIPALITY-KENYA-.pdf

Lanarc HB. 2013. The urban farming guidebook: planning for the business of growing food in BC's towns and cities. Canada (AF): Nanaimo.

[Pemprov] Pemerintah Provinsi DKI Jakarta. 2017. Desain besar pertanian perkotaan Provinsi DKI Jakarta tahun 2018-2030

Sardiman AM. 2004. Interaksi dan motivasi belajar mengajar. Jakarta (ID): PT. Raja Grafindo Persada.

Sihgiyanti VJ. 2016. Evaluasi impelementasi program urban farming oleh dinas pertanian di Kota Surabaya. Kebijakan dan Manajemen Publik [Internet]. [diunduh pada tanggal 29 September 2017]; Vol. 4(2): 264-272. Dapat diunduh di: http://journal.unair.ac.id/download-fullpapers- kmpda2908f5e4full.pdf

Singarimbun M, Sofie E. 2014. Metode penelitian survei. Jakarta (ID): LP3ES.

Tallei TE, Rumengan IF, Adam AA. 2017. Hidroponik untuk pemula. Manado (ID): UNSTRAT Press. 